МАГРАНОВ Алексей Сергеевич - кандидат социологических наук, старший научный сотрудник Центра социально-политических исследований Южного федерального университета (344006, Россия, г. Ростов-на-Дону, ул. Большая Садовая, 105/42); ведущий научный сотрудник ЮжноРоссийского филиала Федерального научно-исследовательского социологического центра РАН (Россия, г. Ростов-на-Дону; alex_daredevil@mail.ru)

ПАНФИЛОВА Юлия Сергеевна - кандидат социологических наук, доцент кафедры политологии и этнополитики Южно-Российского института управления - филиала Российской академии народного хозяйства и государственной службы при Президенте РФ (344002, Россия, г. Ростов-на-Дону, Пушкинская ул., 70; panfilovajulia@mail.ru)

\title{
ПАТРИОТИЧЕСКАЯ САМОИДЕНТИФИКАЦИЯ И ОТНОШЕНИЕ К ПРОТЕСТНОЙ АКТИВНОСТИ В СОЗНАНИИ СТУДЕНЧЕСКОЙ МОЛОДЕЖИ РОСТОВСКОЙ ОБЛАСТИ
}

\begin{abstract}
Аннотация. В статье анализируются особенности отношения к протестной активности среди студентов с эмоционально-чувственной и активно-деятельностной патриотической самоидентификацией. Эмпирической основой исследования стали результаты опроса студенческой молодежи, реализованного при участии авторов. Авторы делают вывод, что эмоционально-чувственные патриотические установки присущи студентам, которые не рассматривают протест как форму борьбы за свои права. В то же время эта группа студентов реже ориентирована и на конструктивную социальную активность. Среди студентов, проявляющих деятельностное начало в патриотической самоидентификации, доля воспринимающих протестную активность как инструмент борьбы за свои права гораздо выше. При отсутствии условий и форм социальной активности, удовлетворяющих запросы этого сегмента молодых людей, мотивы участия в протестах при определенных условиях могут актуализироваться.
\end{abstract}

Ключевые слова: студенческая молодежь, патриотизм, патриотическая самоидентификация, протестная активность

П оследние десятилетия в жизни нашей страны были связаны с огромными социально-экономическими и политическими потрясениями. Периоды социальной нестабильности характеризуются не только проблемами в сферах экономики и политики, но и усилением социальной напряженности и активизацией протестных настроений. Особую группу риска при этом представляет молодежь, для которой, как отмечают исследователи, протестные настроения атрибутивны [Габа 2015].

В русле данной проблематики ученые говорят о различиях в интенсивности и форме выражения протестных настроений молодых людей в зависимости от типа их ментальных программ, места проживания в разрезе территориальной дифференциации, степени доверия институтам власти [Верещагина, Зайцева 2020; Дементьева 2016; Аюшеева 2019]. В то же время, несмотря на наличие специфики, исследователи сходятся во мнении, что гражданско-политические практики, инициируемые «сверху» для конструктивной реализации гражданского участия, вызывают у большинства молодых людей отторжение, которое потенциально может конвертироваться в протестную активность.

Протест в рамках настоящего исследования понимается в контексте теории депривации как осознание невозможности достижения жизненных ценностей никаким иным способом, кроме осуществления социальных и политических изменений в короткий срок. Говоря о типах патриотической самоидентифи- 
кации, выделим эмоционально-чувственный и активно-деятельностный ее типы. Первый тип базируется на значимости патриотизма как эмоционального отношения к родине, ее истории, достижениям, сопричастности к истории и культуре; второй - на деятельности, которая воспроизводится в условиях социальной реальности под воздействием институциональных правил и ресурсов, а также габитуса.

В феврале-июне 2020 г. Центр социально-политических исследований Южного федерального университета провел социологическое исследование «Образ Великой Отечественной войны в представлениях современного российского студенчества: проблемы гражданской идентификации и гражданскопатриотического воспитания» (руководитель В.И. Филоненко). В рамках исследования был проведен анкетный опрос студентов (специалисты, бакалавры, магистранты) и аспирантов 8 вузов и 3 филиалов вузов Ростовской обл., а также учащихся колледжа и СОШ. Общая выборка анкетирования - 1841 чел.

Отдельное внимание в реализованном проекте было уделено изучению отношения студенчества к протестной активности. Как следует из полученных данных, представители студенческой молодежи склонны считать протесты и митинги одной из доступных им форм отстаивания своих прав и свобод. Среди них 28,8\% полагают, что участие в различных протестных акциях - единственно возможный способ реального влияния на ситуацию в обществе, а 27,4\% относятся с пониманием к целям протестующих, но сами не одобряют данный метод. Для 16\% опрошенных студентов протестные акции, равно как и участие в них представителей молодого поколения, абсолютно безразличны. Лишь 7,3\% воспринимают протесты и митинги как провокации, не несущие в себе ничего созидательного. Особый интерес представляет тот факт, что каждый пятый студент $(20,5 \%)$ не смог дать однозначный ответ на поставленный вопрос. Вероятнее всего, к категории «не определившихся» относятся молодые люди, испытывающие затруднения с оценкой целей, которые ставят перед собой протестующие. То есть, они не могут определить, как бы они поступили в той или иной ситуации угнетения своих прав и свобод. Именно причина проведения протестных акций будет служить для них определяющим фактором участия либо неучастия. Данное обстоятельство делает категорию «не определившихся» своеобразным резервом, который может сыграть решающую роль при определенных условиях. Однако роль этого резерва может быть весьма неоднозначной. Он может как использоваться для достижения социальной справедливости, так и стать объектом идеологического воздействия пропаганды экстремистских организаций.

Особого внимания заслуживает тот факт, что отношение представителей студенческой молодежи к участию в протестных акциях и митингах зависит от патриотических установок респондентов. В ходе проведенного исследования было выявлено, что поддержка участия молодежи в протестной деятельности имеет обратно пропорциональную связь с гражданской самоидентификацией студентов вузов. Так, если акции протеста поддерживает только каждый пятый респондент, отметивший, что гордится своей гражданской принадлежностью $(20,9 \%)$, то среди тех, кто испытывает чувство стыда от того, что является россиянином, почти половина $(48,6 \%)$ назвали митинги и протесты единственным способом борьбы за свои права. Вдобавок среди тех, кто гордится своей гражданской принадлежностью, каждый десятый $(10,7 \%)$ считает акции протеста не чем иным, как провокациями, и испытывает к ним только негативные эмоции. Наивысшую степень безразличия к различным проявлениям протестной деятельности демонстрируют молодые люди, которые схожим образом оценивают и собственную гражданскую принадлежность (19,5\%). 
Тем не менее необходимо отметить один момент. Представители студенчества, испытывающие чувство гордости от того, что являются россиянами, значительно чаще остальных выражают понимание участия молодежи в протестных акциях $-31,4 \%$. Кроме того, среди них каждый пятый $(21,1 \%)$ не смог дать однозначную оценку фактам участия сверстников в протестной деятельности. Данная тенденция говорит о том, что эта категория молодежи понимает наличие безнаказанных фактов несправедливости в современном обществе, но в то же время их гражданская идентичность не позволяет им действовать радикально. Это служит еще одним доказательством выделенной тенденции наличия категории «не определившейся» молодежи среди студенчества, которая может перейти к активным действиям в случае ущемления определенных прав и свобод.

Схожая тенденция наблюдается и в распределении оценок представителей студенческой молодежи в зависимости от степени выраженности у них патриотических чувств: чем меньше выражено чувство патриотизма, тем выше степень поддержки участия сверстников в протестных акциях и митингах. Здесь были выявлены две тенденции. Во-первых, наибольшую степень безразличия к протестам демонстрируют студенты, отрицающие наличие у себя чувства патриотизма, $-21,6 \%$. Данный факт можно объяснить тем, что отсутствие патриотической самоидентификации обусловливает исчезновение чувства сопричастности и сопереживания судьбе своей страны. Во-вторых, представители студенческой молодежи, ощущающие у себя чувство патриотизма, в большей степени, нежели остальные, выражают понимание участия молодых людей в различных акциях протеста. Иными словами, здесь прослеживается та же тенденция, которая была выделена в корреляции с отношением к своей гражданской принадлежности.

При этом необходимо обратить внимание на условия, в которых студенты проходили первые этапы социализации. Как следует из результатов проведенного социологического исследования, молодые люди, поддерживающие участие их сверстников в протестных акциях, росли во вполне обеспеченных семьях: у большинства тех, кто считает протесты единственной действенной формой борьбы за свои права, родители занимают достаточно высокое социальное положение. Так, у представителей данной категории отцы являются руководителями структурных подразделений (цеха, отдела и т.д.) компаний и предприятий $(37,5 \%)$, предпринимателями $(35,1 \%)$, а также руководителями предприятия, учреждения или их заместителями $(31,9 \%)$. Кроме того, у $38,3 \%$ респондентов, поддерживающих митинги, матери занимают высшие руководящие должности в компаниях, у 34,3\% - работают в органах местного самоуправления, а $32,6 \%$ занимаются предпринимательской деятельностью.

Обратимся к результатам корреляционного анализа ответов на вопросы об отношении к участию молодежи в массовых протестах и о понимании сущности патриотизма. Как следует из полученных данных, восприятие патриотизма как любви к своей Родине присуще прежде всего студентам, абсолютно негативно воспринимающим акции протеста, $-61,5 \%$. Представители этой когорты отрицают любые формы борьбы за свои права в том случае, если они могут оказать разрушительное воздействие на ситуацию в стране. Помимо этого, патриотизм как проявление любви к своей стране отражается в представлениях молодых людей, относящихся к протестам с безразличием. Тем не менее у студентов, безразличных к акциям протеста, чаще всего встречается понимание патриотизма как защиты своей страны от любых нападок и обвинений $-25,4 \%$. То есть, они в большей степени придают первостепенное значе- 
ние внешнеполитическим факторам, нежели внутриполитическим. Что касается представителей студенческой молодежи, считающих митинги эффективной формой борьбы за права, то у них оказалось более развито деятельностное начало: у данной категории молодежи преобладает восприятие патриотизма как стремления к изменению положения дел в стране, чтобы обеспечить ей достойное будущее, $-52,9 \%$. Кроме того, среди них чаще встречается понимание патриотизма как высказывания правды о своей стране, даже если она горькая, $-26,2 \%$.

Особый интерес представляет анализ основных причин включения студенческой молодежи в протестную деятельность. Согласно результатам проведенного исследования, главным мотивом включения молодых людей в протестную активность выступают факты проявления социальной несправедливости - 42,7\%. Вторую позицию занимают причины материального характера $36,2 \%$ опрошенных считают ухудшение финансового благополучия основной мотивацией включения их сверстников в протестную деятельность. Помимо этого, молодые люди оказались весьма восприимчивыми к фактам несправедливости, являющимся следствием действий власти и государственных структур. Четверть студентов $(25,1 \%)$ указали в качестве главной причины молодежных протестов неправомерные действия со стороны представителей полиции и других силовых структур, а еще $23,4 \%$ считают, что молодых людей могут подтолкнуть к радикальным действиям факты вызывающего поведения или безнаказанные противоправные действия олигархов и чиновников. Также для 22,5\% мотивом протестной активности выступают действия государственной власти, а также принятие непопулярных законов, затрагивающих определенные слои населения. Студенты не исключают и политическую подоплеку молодежных протестов - 6,9\% отметили вовлечение молодежи в протестную деятельность оппозиционными политиками. Кроме того, мотивом для включения представителей молодого поколения в протестную деятельность могут служить факты различных видов дискриминации: возрастной $(12,3 \%)$, расовой $(12 \%)$ или гендерной $(10,4 \%)$.

Стоит отметить, что мотивация протестной активности студенческой молодежи также зависит от социального положения их родителей. Так, у молодых людей, считающих ухудшение материального благополучия основным мотивом включения подрастающего поколения в протестную деятельность, отцы чаще всего являются пенсионерами (42\%), специалистами технического, гуманитарного, экономического, или медицинского профиля $(41,3 \%)$, квалифицированными рабочими $(41,2 \%)$; их матери в основном пенсионеры $(57,5 \%)$, руководители структурных подразделений $(46,2 \%)$ или служащие (секретарь, лаборант, кассир и т.п.) - 40,6\%. Примечательно, что факты проявления социальной несправедливости отмечали в качестве главного мотиватора к протестным действиям в большинстве своем студенты, у которых оба родителя являются специалистами технического, гуманитарного, экономического или медицинского профиля (отец $-49,5 \%$, мать $-51,8 \%)$. Действия государственной власти, принятие непопулярных законов, затрагивающих определенные слои населения, указывали чаще всего молодые люди, родители которых - неквалифицированные рабочие (отец $-32,8 \%$, мать $-34,3 \%$ ).

Была выявлена зависимость мотивации к участию в протестах от патриотической самоидентификации. Как следует из результатов сравнительного анализа, наибольшую склонность к материальному фактору выразили молодые люди, полностью отрицающие наличие у себя патриотических чувств $(48,3 \%)$. А вот включение молодежи в протестную деятельность вследствие влияния 
оппозиционных политиков отмечали в основном студенты с выраженным чувством патриотизма (12,6\%). Это вполне находит свое объяснение в их высоком уровне доверия государственной власти, а также в представлении о протестах как сугубо провокационных явлениях. Стоит заметить, что представители студенческой молодежи, полностью отрицающие наличие у себя патриотических чувств, оказались более восприимчивыми к неправомерным действиям силовых структур - 38,2\% среди них указали данный фактор как основной мотиватор протестной активности подрастающего поколения.

Особого внимания заслуживает тот факт, что четверть опрошенных студентов $(24,7 \%)$ затруднились с ответом на вопрос об основных причинах участия молодежи в протестах и митингах. То есть, это представители все той же категории «не определившихся», не обладающих представлением о том, что именно может толкнуть их к радикальной активности. Именно отсутствие у них четких представлений о грани дозволенного делает их уязвимыми для идеологического влияния различных политических сил, в т.ч. и экстремистской направленности.

Таким образом, как показали результаты исследования, отношение к протестной активности отличается в группах студентов с разными типами патриотической самоидентификации. Эмоционально-чувственные патриотические установки присущи студентам, негативно относящимся к акциям протеста. В целом, этот сегмент студенческой молодежи не пополняет собой так называемый протестный резерв - «не определившихся», которые при определенных условиях могут выйти на улицы. В то же время можно отметить, что эту часть студенческой молодежи будет трудно встроить и в конструктивные практики социальной активности: сравнение данной группы с деятельностными активистами по всем вопросам исследования не показало среди них высокой ориентации на патриотические мероприятия и социальные проекты, требующие какой-либо роли, кроме пассивного наблюдателя.

Если говорить о сегменте студентов, проявляющих деятельностное начало в патриотической самоидентификации, то здесь доля воспринимающих протестную активность как инструмент борьбы за свои права гораздо выше. Более того, в этой группе значительно острее воспринимаются проявления социального неравенства и несправедливости, особенно теми студентами, семьи которых можно отнести к категории слабо защищенных. При этом политические мотивы включения в протестную деятельность в общем спектре мотивов выражены достаточно слабо. В сложившейся ситуации важно понимать, что сегодня при отсутствии условий и форм социальной активности, удовлетворяющих запросы этого сегмента молодых людей на реализацию деятельностных форм социальных практик, перечисленные мотивы участия в протестах могут при наличии повода актуализироваться с новой силой. Это ставит перед институтами социализации, в т.ч. и системой высшего образования, новые вызовы, когда инициативы «сверху» и невнимание к запросам студентов могут стать причиной перехода деятельностных форм активности в деструктивное русло.

Отдельного внимания заслуживает группа студенческой молодежи, отрицающая у себя патриотическую самоидентификацию. С одной стороны, доля тех, кто видит себя участником протестных акций, в этом сегменте в целом невысока, что можно объяснить низким чувством сопричастности к тому, что происходит в стране. С другой стороны, анализ их мотивов возможного участия в протестной активности показывает особую роль материальных факторов, вопросов социальной несправедливости, неравенства в правах. Таким образом, в случае обострения действия соответствующих групп факторов эта 
категория студенческой молодежи также может стать резервом протестной активности.

\section{Список литературы}

Аюшеева Д.А. 2019. Участие молодежи в протестных акциях в современной России как способ самоидентичности. - Управленческое консультирование. № 6. С. 147-153.

Верещагина А.В., Зайцева А.А. 2020. Факторы социального поведения студентов вузов Ростовской области в гражданской сфере. - Государственное и муниципальное управление. Ученые записки. № 3. С. 233-240.

Габа О.И. 2015. Молодежь как субъект протестных настроений. - Знание. Понимание. Умение. № 1. С. 144-151.

Дементьева И.Н. 2016. Протестные настроения молодежи Вологодской области. - Вопросы территориального развития. № 1(31). Доступ: http://vtr.isert-ran. ru/article/1767 (проверено 14.05.2021).

MAGRANOV Aleksei Sergeevich, Cand.Sci. (Soc.), Senior Researcher at the Center for Socio-political Studies, Southern Federal University (105/42 Bolshaya Sadovaya St, Rostov-on-Don, Russia, 344006); Leading Researcher at the South Russian Branch of the Federal Center of Theoretical and Applied Sociology, Russian Academy of Sciences (Rostovon-Don, Russia; alex_daredevil@mail.ru)

PANFILOVA Julija Sergeevna, Cand.Sci. (Soc.), Associate Professor of the Chair of Political Science and Ethnopolitics, South Russian Institute of Management - Branch of the Russian Presidential Academy of National Economy and Public Administration (RANEPA) (70 Pushkinskaya St, Rostov-on-Don, Russia, 344002; panfilovajulia@mail.ru)

\section{PATRIOTIC SELF-IDENTIFICATION AND ATTITUDE TO PROTEST ACTIVITY IN THE MINDS OF STUDENTS OF THE ROSTOV REGION}

\footnotetext{
Abstract. The aim of this article is to identify the attitude to protest activity among students with different types of patriotic self-identification. Speaking about the types of patriotic self-identification, the authors distinguish emotional-sensual and active-activity types. The first type is based on the significance of patriotism as an emotional attitude to the homeland, its history, achievements, involvement in history and culture. The second is based on activities that are reproduced in the context of social reality under the influence of institutional rules, resources, and habitus. The results of the study showed that the attitude to protest activity differed in groups of students with different types of patriotic self-identification. Emotionally sensitive patriotic attitudes are inherent in students who have a negative attitude to protest actions. These students do not view protest as a form of struggle for their rights. Among students who show an active beginning in patriotic self-identification, the proportion of those who perceive protest activity as an instrument for the struggle for their rights is much higher. Moreover, this group is much more sensitive to social inequality and justice, especially if their families can be classified as vulnerable. In the absence of conditions and forms of social activity that meet the needs of this segment of young people for the implementation of active forms of social practices, the listed motives for participating in protests may be updated if there is a reason.

Keywords: student youth, patriotism, patriotic self-identification, protest activity
} 